\title{
Interaction between magmatic and tectonic stresses during dyke intrusion
}

\author{
Jorge Skarmeta
}

Gerencia de Exploraciones, Codelco Chile, Huérfanos 1270, Santiago, Chile.

jskarmet@codelco.cl

\begin{abstract}
Cataclastic and mylonitic rocks exposed in the southwestern part of the Peninsula de Mejillones, northern Chile, are intruded at high angles of the foliation by younger, steeply inclined $\left( \pm 70^{\circ}\right)$ basaltic dykes that resemble intrusive tension gashes with knife-edge contacts with the country rocks. These late dykes developed sigmoidaly-shaped, preferred orientation paths defined by oriented pyroxene phenocrysts that vary in size, aspect ratio, concentration and distribution across the width of an individual dyke. This banding has $z$ and $s$ asymmetries that indicate the sense of displacement of the country rock. The relative involvement of the coeval, internal and external stresses that caused the finite strains is estimated by using a partition analysis. The phenocryst location and size distribution are related to the internal magma flow velocity $\left(u_{m}\right)$ stress component, whereas the sigmoid banding is linked to the external tectonic wall displacement velocity $( \pm u)$. Dyke wall sliding with or against the magma flow induced the asymmetric shear strain distribution.

The measured strain and displacements are analyzed using the deformation model of viscous laminar flow confined between two parallel plates moving parallel to each other with opposed motion. The shear stresses related to magma intrusion and frictional dyke-wall shear are quantified on the basis of magma flow displacements, cooling times and the temperature dependent viscosity of basalts in the linear rheology range. At the estimated depth where the intrusion and deformation occurred, the state of stress was close to being hydrostatic. This conclusion is in agreement with established models of active-collapsing volcanic centres, where bulk permeability is accommodated by means of a mesh of interconnected dykes and active faults. This interactivity tends to re-equilibrate, locally and transiently, any excess differential stress and redistributes excess magmatic pressures to create a uniform hydrostatic stress regime.
\end{abstract}

Keywords: Basaltic dykes, Shape preferred orientation, Magmatic and tectonic stress, Magmatic faulting, Magma viscosity, Hydrostatic regime.

RESUMEN. Interacción entre esfuerzos magmáticos y tectónicos durante la intrusión de diques. Las rocas cataclásticas y miloníticas expuestas en la parte suroeste de la Península de Mejillones del norte de Chile están intruidas por un sistema de diques basálticos de alta inclinación $\left( \pm 70^{\circ}\right)$. Estos muestran contactos intrusivos netos, grietas de tensión e internamente una orientación sigmoidal definida por un alineamiento de fenocristales de piroxeno, los que decrecen en tamaño y concentración desde el centro hacia los bordes de los diques. A partir de la geometría de la orientación preferencial se establecen los sentidos de desplazamiento de las rocas de caja, los que corresponden a sistemas de cizalle conjugados, con asimetrías en $s$ y $z$ respectivamente. La participación relativa de los esfuerzos fue segregada en una componente interna o magmática y una externa o tectónica. La zonación y concentración de los fenocristales están relacionadas con el flujo magmático $\left(u_{m}\right)$, mientras que la orientación sigmoidal preferente con los esfuerzos tectónicos asociados con el desplazamiento $( \pm u)$ de la roca de caja. El desplazamiento de las fallas, a favor o en contra del flujo magmático, induce la asimetría de la deformación de cizalle finita.

La deformación y el desplazamiento se analizan en conjunto con modelos de deformación de flujos viscosos y laminares contenidos entre dos placas paralelas con movimiento en el sentido opuesto. Los esfuerzos de cizalle derivados de la intrusión de magma y del fallamiento son cuantificados sobre la base de desplazamientos de flujos magmáticos, tiempos de enfriamiento y viscosidad de los magmas basálticos en el rango de la reología lineal. Para la profundidad estimada de intrusión y deformación, el estado de esfuerzos fue cercano al hidrostático. Esta conclusión es concordante con los modelos establecidos para el colapso de centros volcánicos activos en donde la permeabilidad es acomodada por mallas interconectadas de diques y fallas activas. Esta interconectividad tiende a equilibrar las presiones supra-hidrostáticas, transcientes y locales, y a distribuir el exceso de presión magmática para mantener los equilibrios hidrostáticos. 


\section{Introduction}

Dyke intrusion is one of the most efficient mechanisms for transporting magma from deep reservoirs to shallow levels in the crust. Their advance is driven by the internal excess pressure of the magma which results in brittle fracture of the surrounding non-deforming media. The direction of crack propagation is determined by the orientation of stress at the crack-tip and is assumed to be perpendicular to the least compressive principal stress (Rubin, 1995; Baer, 1995). At shallow crustal levels the principal stress orientations are either vertical or horizontal (Anderson, 1951). Therefore sheet-like intrusions along Mode I fractures will be either horizontal, or more commonly vertical.

However, dyke injection is not restricted to Mode I fractures. If, because of the addition of a tectonic stress to that of the overburden, the differential stress at the site of injection becomes greater than $\sim 4 \mathrm{~T}$ (where $\mathrm{T}$ is the tensile strength of the rock), the rock will fail by shear failure and the dyke will be injected along a shear fracture (Escher et al., 1976). If the maximum principal stress is vertical, conjugate shear fractures dipping at $\sim 60^{\circ}$ (i.e., normal faults) will develop. In addition, as in the study area of the Peninsula de Mejillones for example, dyke intrusion may occur along pre-existing fractures, which in this locality are shear fractures. Regardless of when the shear fractures were formed, any magma injected along them may cause reactivation and therefore be subject to shearing along the fracture walls. This departure from an 'Andersonian' state of stress (Anderson, 1951) will typically give rise to dykes with an en-echelon orientation (Pollard, 1987), offsets and curved geometries (Delaney and Pollard; 1981), lateral drag folds, (Rickwood, 1990; Smith, 1987; Baer, 1995), shape-preferred orientation fabrics (SPOs) developed by the re-orientation of rigid particles immersed in a viscous fluid (Arbaret et al., 1996), crystal tiling (Den Tex, 1969; Blumenfeld and Bouchez, 1988) and magma gashes. All these features are indicators of the existence of shear stress resolved on the dyke plane.

Propagating dykes subjected to both an internal stress field i.e., the magma pressure, and a shear parallel to the dyke margins will develop internal strains, flow fabrics and asymmetric preferred directional orientation or shape fabrics in the dyke system, and may also induce host rock failure or fault reactivation.
In this paper, the mechanism of dyke emplacement into fractures, parallel to which there is a shear stress, is analyzed. Two major aspects are considered:

i. The magmatic pressure that drives the magma flow and induces the related phenocryst size segregation and concentration dispersion across the dyke.

ii. The external or tectonic shearing that displaces the dyke host rocks during or shortly after the crystallization of the magma. This leads to mechanical interactions between crystals during or shortly after the temperature has decreased to the point at which deformation is inhibited because of the crystalization control on magma rheological behaviour. The shearing applied on the cooling-crystallizing magma will favour the generation of a SPO fabric and crystal tiling.

The model is tested on a series of basaltic dykes that intrude basement rocks exposed in the southern part of the Peninsula de Mejillones, in northern Chile. These dykes were probably parts of the feeder system to the major volcanic arc that lies in the Coastal Cordillera in northern Chile. They present notable features that illustrate the effects of an external fault-related shear stress during emplacement. This shearing has resulted in the formation of internal asymmetric sigmoidal SPO (Figs. 1 and 2), and the coeval internal magmatic flow differentiations that can account for size and concentration variations of phenocrysts across the dyke width (Fig. 3).

\section{Geological setting and dyke structure}

The south-western part of the Peninsula de Mejillones in northern Chile is underlain by a $20^{\circ}$ to $70^{\circ} \mathrm{E}$ trending band of anastomosing mylonitic and protomylonitic gneisses developed in a granitic to gabbroic migmatitic complex of Lower Jurassic age, ca. 200 My (Baeza, 1984; Cortés et al., 2007). The cataclastic and mylonitic rocks exhibit a complicated deformational history with abundant microtextural structures characteristic of a major heterogeneous shear zone that locally grades towards less deformed rocks (Skarmeta and Suárez, 1979). The whole system was subsequently cut by brittle Meso-Cenozoic faults (González, 1996; Cortés et al., 2007). Available paleomagnetic data from the mylonitic complex indicate a scattered distribution 


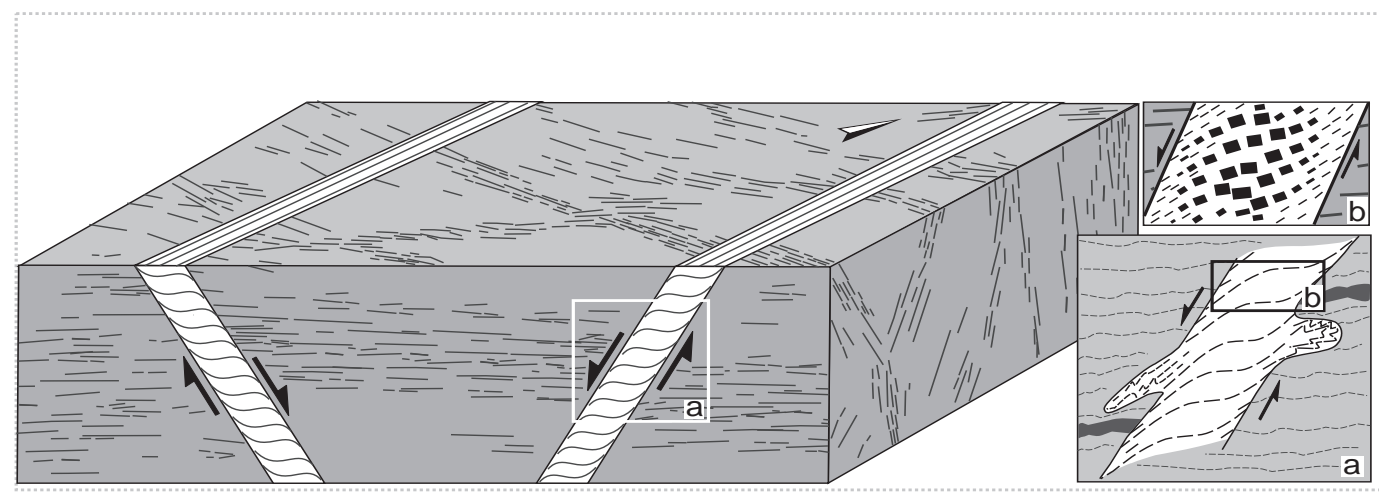

FIG. 1. Block diagram showing the sigmoidal shape preferred orientation (SPO) within dykes and sense of dyke-parallel displacement of the adjacent country rock. Note that the west block has dropped relative to the east one along the west dipping dykes, and the east block has dropped along the east dipping dyke, generating $z$ and $s$ asymmetries within the dykes. a. intrusive contact relations (see Fig. 2) and pre dyke displacement of syn-metamorphic dykes (shown in black), and b. is a schematic representation of size and grain concentration towards the centre of the dyke (see Fig. 3).

that has been interpreted as being due to minor, localized, non-uniform, block-fault related rotation after 158 Ma with no significant large-scale latitudinal translation (Hartley et al., 1992).

The mylonitic basement country rock is crosscut by three suites of dykes of pre, syn and post metamorphic/deformation age. The pre-metamorphic dykes consist of dark green amphibolites with a well defined foliation parallel to the country rock fabric. The syn-metamorphic dykes are metadiabases and aplites emplaced parallel to the main foliation. The post-metamorphic dykes are basaltic in composition, intrude all previously deformed rocks, and do not contain metamorphic minerals. González (1996) suggested a Jurassic age for these dykes and Baeza (1984) indicated that they may represent the roots and/or feeders of the major Jurassic volcanic arc (La Negra Formation, Ferraris and Di Biase, 1978) widespread along the Coastal Cordillera of northern Chile.

The post-metamorphic dykes have a pronounced sigmoidal SPO that is formed by a mineral alignment of varying intensity which, at the dyke margins, is oblique to the country rock fabric (Skarmeta, 1980; Figs. 1 and 2). The dykes show intra-dyke fabrics that do not have equivalents in the host rocks, as high angle-sharp contacts with the mylonitic foliation of the country rock, V shaped intrusion tension gashes (Hippert, 1993), and stubby apophyses injected into the host rock that tend to parallelism with the parent dyke (Fig. 2). When it is possible to observe these apophyses they face in opposite directions on each margin of a dyke. A few late post-metamorphic dykes were emplaced along pre-existing fault structures, as evidenced by displaced aplitic syn-metamorphic dykes (Fig.1a).

A magmatic origin is favoured for the SPO, de-fined by an alignment of igneous, commonly euhedral minerals, particularly where the banding is parallel to internal or external pluton contacts (Paterson et al., 1989). Most of the late dykes strike between $300^{\circ}$ and $350^{\circ}$ and dip about $75 \pm 5^{\circ}$ to the east or west (Fig.1). They consist of a fine-grained matrix of plagioclase and pyroxene, with pyroxene phenocrysts that vary in size and distribution across the dyke width (Fig. 3). The width of the dykes ranges from 10 to $100 \mathrm{~cm}$, but most commonly falls between 25 and $50 \mathrm{~cm}$. The narrower dykes show a more pronounced and homogeneous crystal size and orientation than the wider ones. When they are greater than $20 \mathrm{~cm}$ in width, the dykes commonly show gradational variations of the phenocryst concentration, size and lath axial ratio across them. This variation is poorer at the margins (Fig. 3a). The central, axial zone contains larger $(>1 \mathrm{~cm})$ and lower axial ratio crystals, with a poorly developed fabric whereas the margins show smaller crystals $(<0.5 \mathrm{~cm})$ with larger axisymetric ratios strongly oriented and tiled (Fig. 2). This size and concentration distribution is a characteristic usually attributed to the grain dispersive pressure generated by the mechanical interactions of phenocrysts during magma flow (Komar, 1976).

The SPO generated by the alignment, pilling up and tiling of pyroxene phenocrysts is generally obli- 


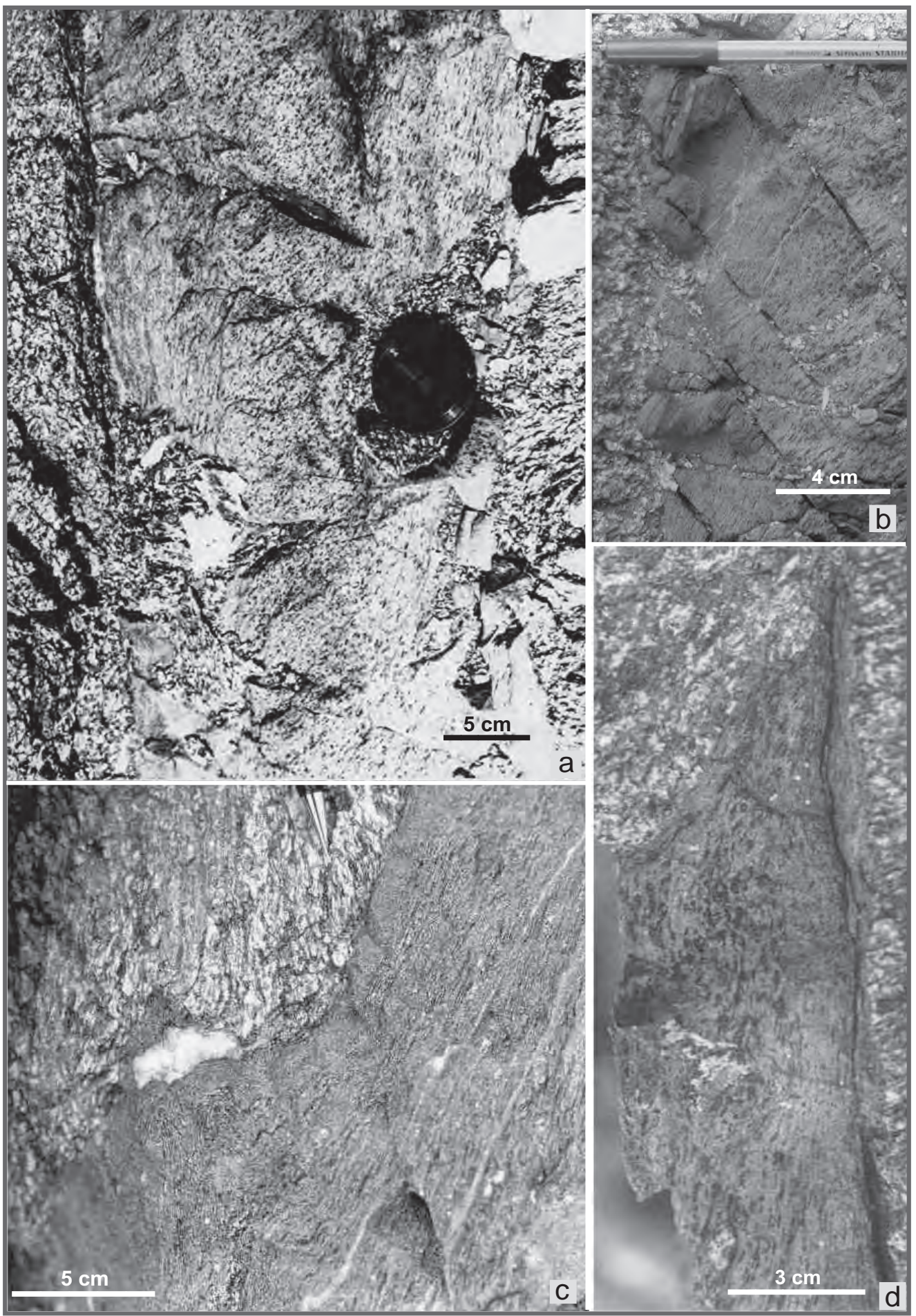

FIG. 2. a. Sheared basaltic dyke from the Peninsula de Mejillones. Note the sigmoidal shape preferred orientation path; b. Detail of dyke margin-host rock contact; c. Tension gash in the host-rock in-filled with basaltic magma containing folded mineral alignments; d. Asymmetric parasitic folds developed in the phenocryst oriented fabric showing the sense of shear in a tension gash. 

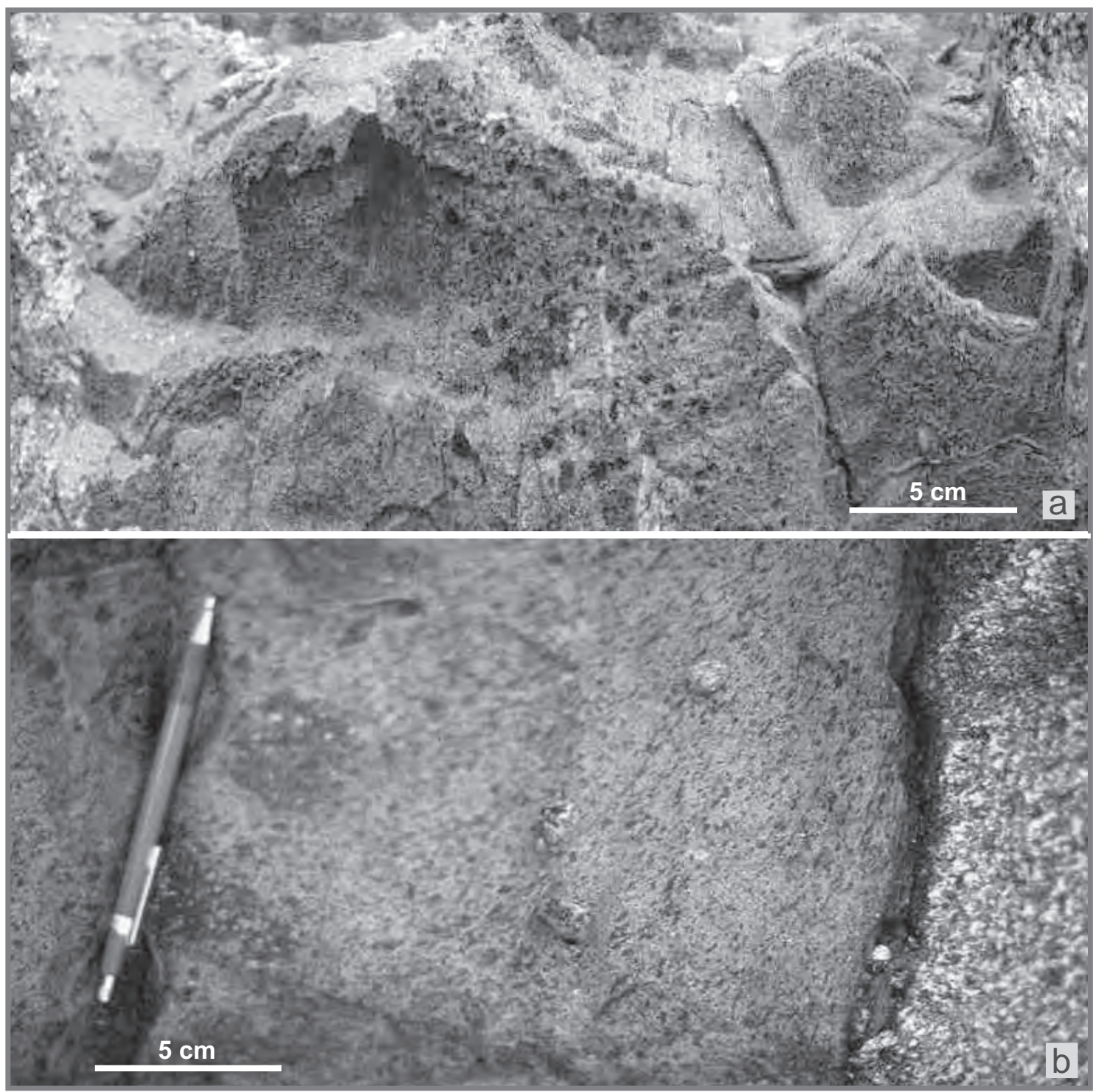

FIG. 3. a. and b. field examples of the characteristic variations of the phenocryst concentration and lath size across dykes.

que to the dyke walls with which it forms a dihedral angle of $30^{\circ}$, and has a sigmoidal geometry. The maximum deformation and crystal rotation occurs at the margins where the SPO forms a dihedral angle of around $3^{\circ}$ as compared to the centre of the dyke where, if it is developed, the SPO forms angles of $50-45^{\circ}$ (Figs. 1 and 2).

Where visible, the acute angle between the long axis of aligned grains and the dyke wall point in the direction of movement of the adjacent country rock. It is generally observed that displacement along the west dipping dykes is down-dip to the west, whereas along the east dipping dykes, it is down dip to the east. This imparts $z$ and $s$ asymmetries to the dyke fabrics (Fig. 1). This structural arrangement suggests that the emplacement of dykes occurred along a conjugate normal fault system. The pre-injection displacements along these faults can be determined from the displacement of markers such as early dykes (Fig. 1a) and the post/syn-injection displacements can be determined from the geometry of the SPO within the dykes. 


\section{Conceptual model}

The intrusion of dykes involves propagation of fractures within the host rock, the injection of fluids into the fracture tip, and the flow of magma within the dyke that gives rise to the core zone where the magma flow fabrics localize (Baer, 1995). The development of these fabrics is mainly governed by stresses that are composed of an internal or 'magmatic pressure', and an external or 'tectonic' stress that can generate local faulting of the host rock and/or fault reactivation.

Magma-related velocity profiles develop in the dyke and their geometry is a function of the magma rheological behaviour. During flow, the velocity gradient induces non-coaxial shear parallel to the flow plane with an opposite sense on each side of the dyke. The shear intensity decreases progressively from the margins towards the centre where the maximum flow velocity is attained (Merle, 1998). Variations in the profiles may be controlled by changes of particle/liquid/volatile proportions within the flowing magma (i.e., viscosity contrast between the pyroxene phenocrysts and matrix and/ or initial concentration and size distribution of particles with respect to matrix), all of which can modify the contact interactions during flow, and also by temperature and strain rates (Gay, 1968; Shaw et al., 1968; Arbaret et al., 2000).

The bulk preferred orientation of kinematic markers can be represented by aligned and/or strained phenocrysts and vesicles (Coward, 1983), xenoliths (Ramsay and Graham, 1970), maximum susceptibility axis (Clemente et al., 2007), preferred lattice orientations (Blumenfeld and Bouchez, 1988; Benn and Allard, 1989; Ildefonse et al., 1992) and shape preferred orientations (Arbaret and Diot, 1996). Magmatic flow induces lateral shearing that rotates markers towards a symmetrical and parallel alignment to the flow direction at the dyke walls. The strain marker alignment is generally symmetrical with respect to the walls and the apex points of the acute angles indicate the direction of the magma source (Fig. 4).

Elliptical fabric flow indicators, subjected to superimposed shear stress on the dyke wall during intrusion and prior to the final cooling of magma, reflect a rotation of the maximum principal strain axis. Three types of orientation between magma flow and the shear stress vector are recognized:
- Flow parallel to shear. When the magma flow direction is parallel to the main shear direction, on one side of the dyke the flow opposes the shear as is shown on the left hand side of figure 4a. Thus the intensity of the resulting shear strain is different and the angle between the SPO in the dyke and the dyke wall will be different.

- Flow perpendicular to shear. With flow perpendicular to shear the maximum strain axis at both margins evolves similarly within the two planes, and the imbrication angle tends to $0^{\circ}$ when the shear strain becomes parallel to the shear vector (Fig. 4b). The strain trajectory in the section shown in figure $4 \mathrm{~b}$ is symmetrical.

- Flow oblique to shear. When magma flow is oblique to shear the resultant rotation pattern will be a combination of the two former cases and an asymmetrical fabric will result (Fig. 4c). From a geometric and a kinematic analysis two planes of symmetry can be defined that are the symmetry plane that splits the dyke longitudinally and the plane defined by the fabric. Symmetrical magmatic fabrics may be produced by magma flow shear or by its combination with external shear. Asymmetric fabrics result mostly from external simple shear strains or simple shear with subordinate pure shear (Correa-Gomes et al., 2001; Clemente et al., 2007).

The internal magma stress is related to the magma flow velocity $\left(u_{m}\right)$, whereas the tectonic stress generates a wall displacement velocity $( \pm u)$, that in the absence of magma is opposed and relative. The concept of dyke walls sliding in opposite directions implies that a wall that moves in the same direction as the magma flow will result in less magma-related lateral shear strains as compared to the wall moving in the opposite sense which will result in a larger
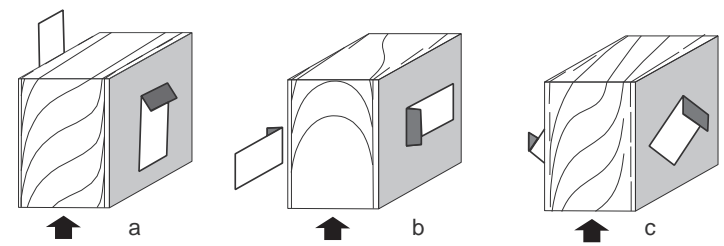

FIG. 4. Rotation of maximum strain axes caused by shear stress resolved on a dyke wall during intrusion. a. Flow parallel to shear; b. Flow perpendicular to shear; c. Flow oblique to shear. Heavy arrow indicates magma flow direction and flat plain arrows the shear stress direction. (Modified from Clemente et al., 2007). 
lateral strain. Figure 5 shows the zones of resultant shear within a dyke under coeval internal and external stress where the relative magnitude of the magma flow velocity with respect to the shear displacement rate on the fracture decreases from left to right.

Five combinations of magma flow velocities and wall displacement velocity have been illustrated (Correa-Gomes et al., 2001). Two cases that result from considering either $u_{m}>>u$ or $u_{m}>u$ show different symmetry arrangements of the strain markers (Fig. 6a and b), both of which are determined by magma flow. In a third case (Fig. 6c) $u_{m}=u$. A fourth case in which $u_{m}<u$ (Fig. 6d) and the acute fabric angles point against the magma flow direction, and finally when $u_{m}<<u$ the finite lath orientation along the conduit is rigorously determined by external shearing. In this case, the border of the conduit that moves in the opposite sense to the magma flow deflects the markers to result in greater asymmetry with a sigmoidal trace as a consequence of the additional relative velocity (Fig. 6e).

The border of a conduit that moves with the magma flow has a smaller resultant relative velocity

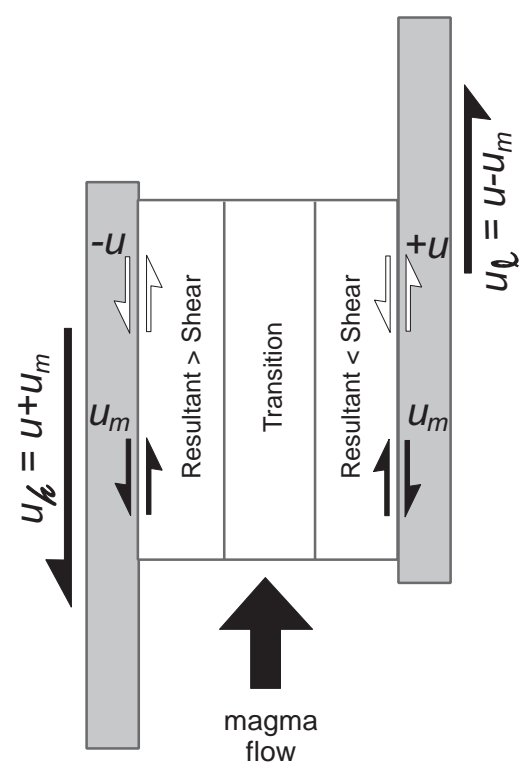

FIG. 5. Schematic representation of three zones in a hypothetical dyke affected by an external shear coeval with an internal magmatic shear. The right wall moves forward in the same sense as the magma flow and the left wall moves in opposition. Positive and negative velocities correspond to resultant shear movements with respect to magma flow. $u$ $=$ wall displacement velocity (white arrows), $u_{m}=$ magma flow velocity (black arrows). and less pronounced shear strain paths than the one moving against the flow, indicating that the intrinsic difference of the fabric obliquity and the asymmetry of the strain trajectories along the shear plane are dynamically related.

The geometry of the strain markers within the dykes from the Peninsula de Mejillones are almost all markedly asymmetric sigmoids of the $u_{m}<<u$ or $u_{m}<u$ types, (Fig. $6 \mathrm{~d}$ and e). This fact suggests that the fabrics were largely shaped by external shearing $(u)$ in the presence of a subordinate magma velocity related pressure, $u_{m}$. This relationship indicates that the principal external deviatioric stresses and the magmatic driving pressure were not in equilibrium at the time of dyke emplacement.

A quantification of both the internal (magma pressure) and the external (tectonic) stress components of the conceptual model illustrated in figure 6 is determined in the following sections and then applied to examples from the Peninsula de Mejillones dyke swarm system.

\section{The tectonic component}

The method used to measure strain and displacement within the dykes is a modification of the model proposed by Ramsay and Graham (1970), with the sole difference being that in the examples considered here, strain and displacement increase towards the dyke edges rather than the centre (Fig. 2). This method is equivalent to that proposed by Arbaret et al. (2000) that describes the deformation of partially crystallised magmas subject to simple shear deformation. This leads to the rotation and relative translation of early-formed crystals embedded in a viscous matrix. Later displacements parallel to the dyke walls are impossible to ascertain with this method of analysis.

The sigmoidal SPO revealed by the oriented pyroxene phenocrysts can be measured in terms of shear strain across the dykes. The coordinate system used is shown in figure 7.

Table 1 shows the variation in density of phenocrysts across a dyke at four locations (A-D) on a single dyke. From this table it can be inferred that the density of the central, least or non-oriented, part of the dyke is identical to the margins with a strong shape orientation. The deformation and crystal realignment process thus occurred at a constant volume. Constant volume deformation, with no deformation 

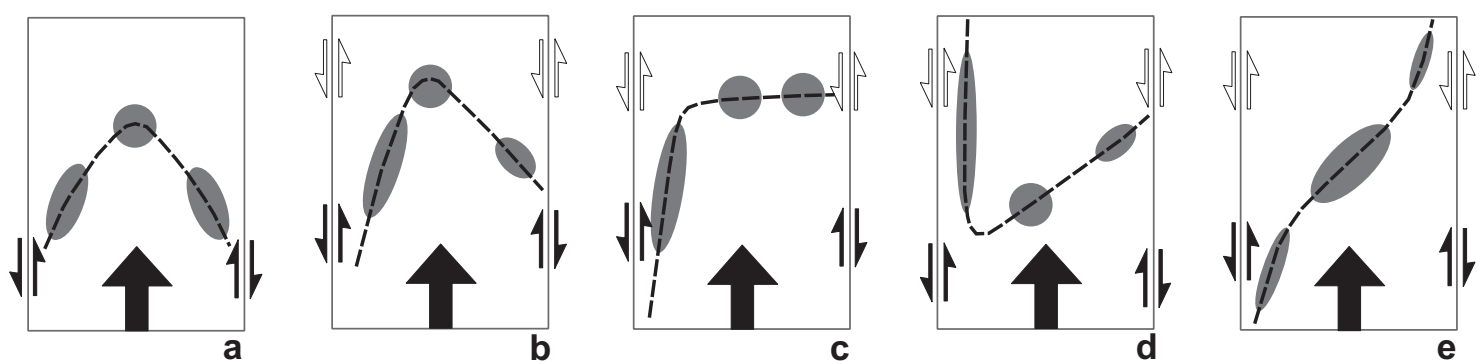

FIG. 6. Shapes and positions of fabric ellipses developed by a shearing induced by external, tectonic-related stress and internal, magma stress in dykes. a. Magma flow velocity $\left(u_{m}\right) \gg>$ wall displacement velocity $(u)$; b. Magma flow velocity $>$ wall displacement velocity; c. Magma flow velocity = wall displacement velocity; d. Magma flow velocity $<$ wall displacement velocity; e. Magma flow velocity $<<$ wall displacement velocity. Black arrow indicates magma flow direction. Circles indicate non sheared state and ellipses the varying grade and orientation of deformation. (Modified from Correa-Gomes et al., 2001).

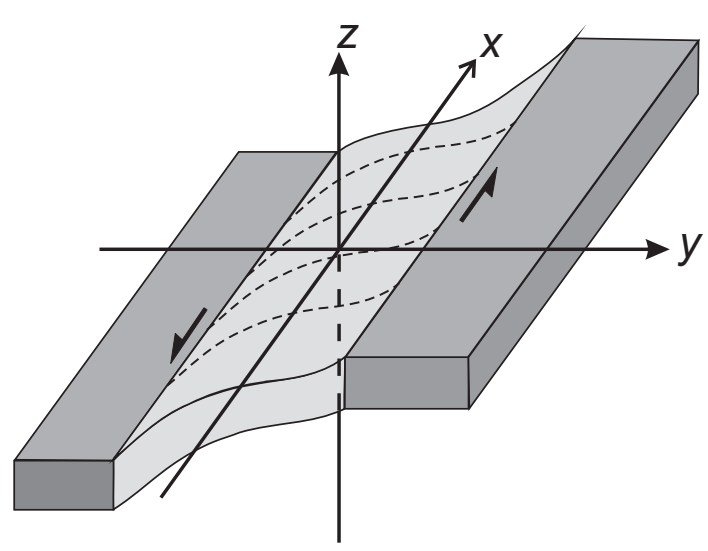

FIG. 7. Cartesian coordinate system used in this study. Dark grey decoration corresponds to the host rock and light grey to the dyke. Dashed lines within the dyke mimic the SPO paths.

perpendicular to the $x-y$ plane (inferred from the homogeneity of the phenocrysts in the $z$ direction, figure 7, see below) corresponds to non-homogeneous plane strain (Ramsay and Huber, 1983). Plane strain at constant volume with a gradation from oriented to non-oriented rocks is best explained by simple shear, as no other displacement pattern can account for all the observed symmetry and strain constraints (Ramsay and Graham, 1970).

The shear strain was measured from more than three hundred oriented pyroxene laths at various positions across the dykes based on Ramsay and Graham (1970), figure 8:

$$
\tan 2 \gamma=\frac{2}{\theta^{\prime}}
$$

TABLE 1. DENSITY DETERMINATIONS ACROSS A DYKE (i.e., FIG. 2a).

\begin{tabular}{ccc}
\hline Sample & Position & $\rho\left(\mathbf{g r} / \mathbf{c m}^{3}\right)$ \\
\hline A & Edge & 2.80 \\
B & Centre & 2.81 \\
C & Centre & 2.81 \\
D & Edge & 2.81 \\
\hline
\end{tabular}

Where $g$ is simple shear and $\theta^{\prime}$ is the angle that the lath major axes orientation forms with the $x$ axes (Figs. 8 and 9). From equation 1 the values of $\gamma$ were calculated across the dyke. Figure 8 shows that, for any infinitesimal width $\partial y$, there should be an infinitesimal displacement $\partial s$ both interrelated by:

$$
\gamma=\frac{\partial s}{\partial y} \quad \text { or } \partial s=\gamma \partial y
$$

Hence the total displacement $\mathrm{S}_{\mathrm{t}}$ across the dyke will become

$$
\mathrm{S}_{\mathrm{t}}=\int_{y=-l}^{\mathrm{y}=\mathrm{h}} \gamma \partial y
$$

The origin of the coordinate system (Fig. 7) corresponds to the place where the dykes show almost zero shear strain (i.e., Fig. 9). In the example shown in 


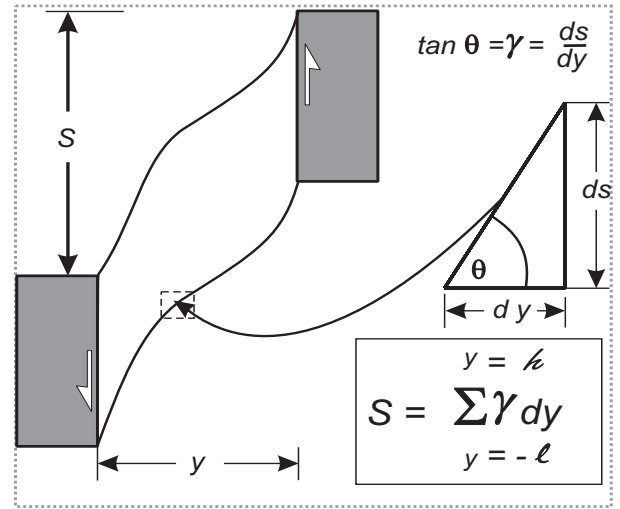

FIG. 8. Diagram showing the relationships between measured infinitesimal shear strain and displacement across a dyke. (Modified from Ramsay and Graham, 1970). figures 9 and 10 the dyke walls occur at -10 and $15 \mathrm{~cm}$ from $y=0$ and hereafter the following nomenclature will be used: $=10 \mathrm{~cm}, h=15 \mathrm{~cm}$ and $-l \leq y \leq h$.

In order to determine $\gamma$ and $S$, around three hundred measurements of $\theta$ ' were taken across several dykes displaying the fabric geometry shown by the dykes in figure 2. These values in equation 1 enable the $\gamma$ variations across the dyke to be determined. These have been plotted over the range $(-10 \leq y \leq 15 \mathrm{~cm})$ and these plots are shown in figure 9 . The area under the $y-\gamma$ curve is the total displacement $\mathrm{S}_{\mathrm{t}}$, and this can be evaluated using equation 3 .

The curves which best fit the plotted points, are three discontinuous polynomials of restricted validity along the $y$-axis. Data from figures $9 \mathrm{a}, \mathrm{b}$ and

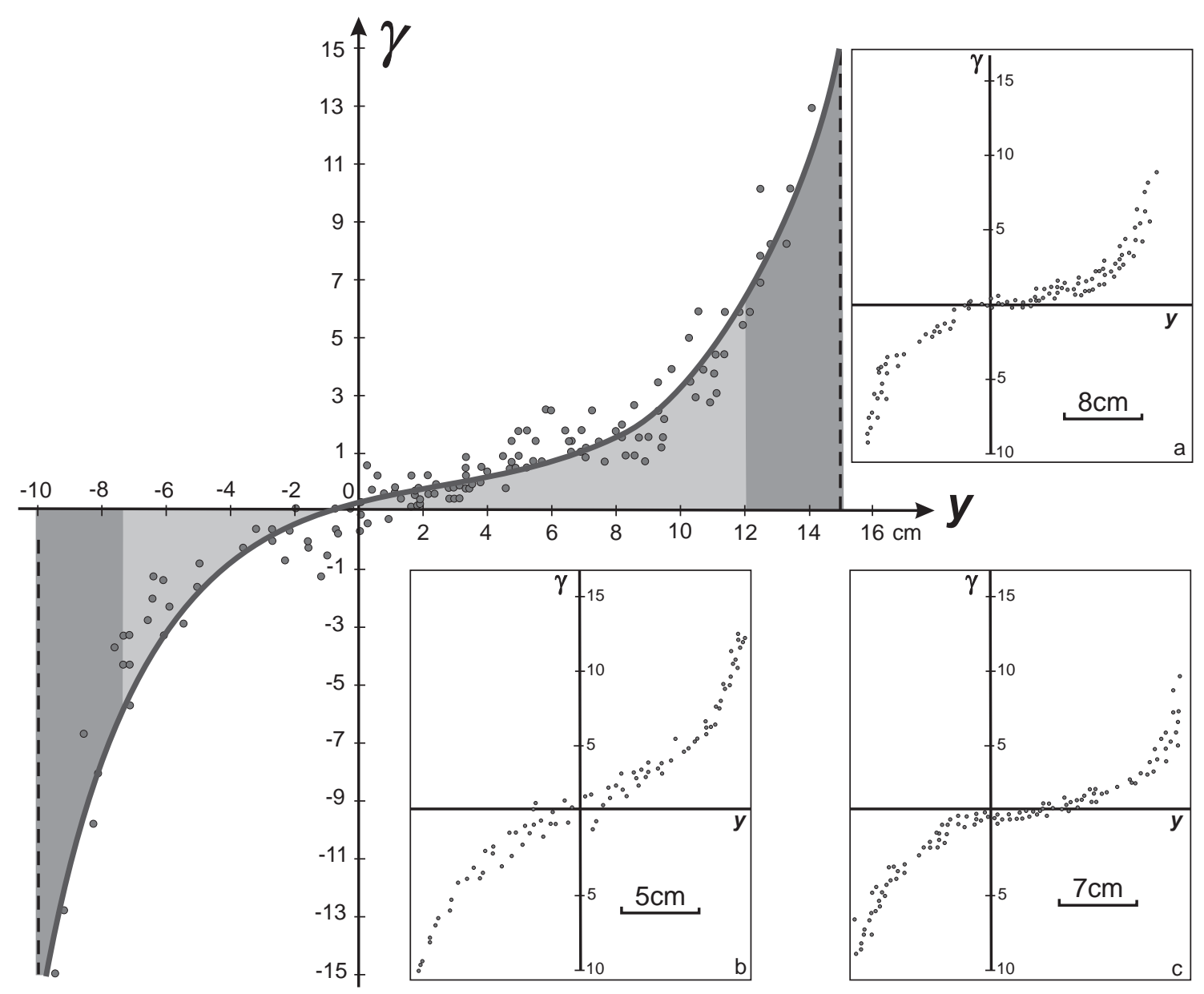

FIG. 9. Shear strain-width curves. a. Values measured across one dyke (as that shown in figure 2a, with the methodology shown in figure 7). The curves correspond to the best-fit equations to these points (text equations 4,5 and 6 ), the total shaded grey area is the total displacement $\mathrm{S}_{\mathrm{t}}(\sim 200 \mathrm{~cm})$ and the dark lateral grey area corresponds to the displacement along the dyke margins. Insets are measurements along other dyke sections, with width scale indicated. 
$8 \mathrm{c}$ were obtained from other cross sections. They show that the discontinuity points have a different relative position at each dyke, thus showing that the strain is non-uniform.

The best fit curves for the $\gamma-y$ graphs are polynomials of the form $\gamma=a_{0}+a_{1} y+a_{2} y^{2}$, where the $a_{i}$ coefficient varies at each dyke.

The equations corresponding to the graphs shown on the three segments of the $\gamma$ axis in figure 9 are:

$$
\gamma_{5}^{15}=1.3-0.5 y+0.1 y^{2}
$$

and

$$
\gamma_{-2}^{5}=0.75-0.1 y-0.002 y^{2}
$$

and

$\gamma_{-10}^{-2}=0.15-0.8 y-0.3 y^{2}$

and the total shear strain $\gamma \mathrm{t}$ will then be

$$
\gamma_{t}=\gamma_{5}^{15}+\gamma_{5}^{-2}+\gamma_{-10}^{-2}
$$

The total displacement $\mathrm{S}_{\mathrm{t}}$ can be obtained from (3)

$$
\begin{aligned}
\mathrm{S}_{\mathrm{t}}=\int_{5}^{15} \gamma_{5}^{15} \partial y & +\int_{-2}^{5} \gamma_{-2}^{5} \partial y \\
& +\int_{-10}^{-2} \gamma_{-10}^{-2} \partial y
\end{aligned}
$$

The result of the evaluation of equation 8 indicates that the total displacement $\mathrm{S}_{\mathrm{t}}$ is close to $200 \mathrm{~cm}$ for this $25 \mathrm{~cm}$ thick dyke. If equation 8 is evaluated only in its central, coarser grained and highly concentrated part, between $y=-4$ and $y=5 \mathrm{~cm}$ instead of $y=-10$ and $y=15$ the displacement $\mathrm{S}_{\mathrm{t}}$ is less than $50 \mathrm{~cm}$, indicating that almost all of the displacement has taken place along the margins of the dyke, where the fragments are smaller, have a lesser aspect ratio and are much less concentrated (Figs. 9 and 10). Such a displacement gradient is probably related to an increased concentration of, and consequent interaction between rigid particles. This may cause the rotation of individual particles to slow-down, or even stop due to collisions or disturbance of the flow in the matrix (Ildefonse et al., 1992). Particle size and axial ratio have a strong control on rotation and development of shape fabric, as described by Jeffreys' (1922 in Arbaret et al., 2000) with the shear strain motion equation:

$$
\gamma=\frac{4 \pi}{\sqrt{1-K^{2}}}
$$

where $K=\left(\xi^{2}-1\right) /\left(\xi^{2}+1\right)$ in which $\xi$ is the shape axial ratio of the particle. From equation 9, two extreme cases can be established: (i) spherical particles placed at the centre of the dyke $(\xi \sim 1)$, will rotate at a constant rate if collision does not slow or inhibit them, and (ii) particles with high axial ratios $(\xi>1)$ rotate towards stabilization and parallelism with the shear direction (Fig. 10).

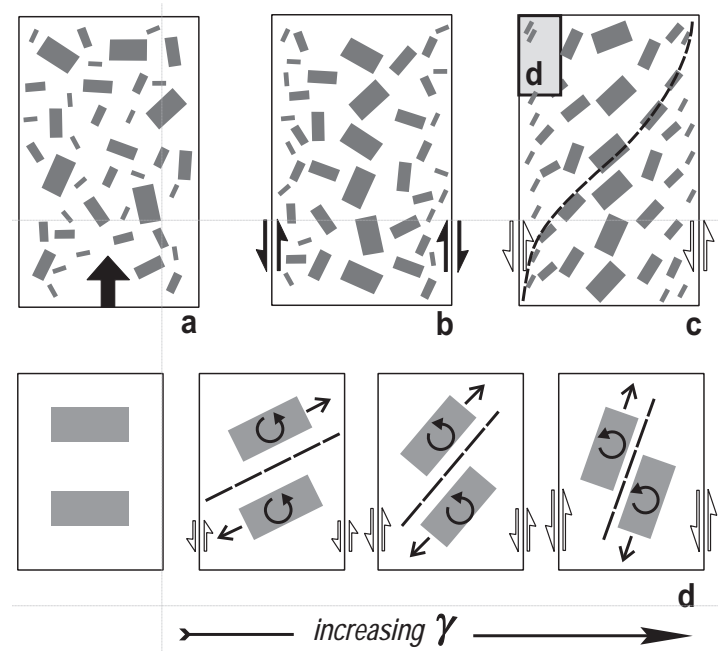

FIG. 10. Schematic representation of the effects of an external fault-related shear stress applied to a magma containing particles with a segregated size and distribution. a. Initial injection of fluids with no size or concentration segregation; $\mathbf{b}$. Intrusion flow velocity profiles that give rise to differentiation that accounts for variations in the size and concentration of phenocrysts across a dyke during magma flow; c. Superimposed shearing caused by wall displacement on a segregated magma giving place to the formation of internal asymmetric sigmoidal SPO mimicked by dashed lines; d. Development of tiling of two particles in sinistral simple shear for increasing $\gamma$ (based in Arbaret et al., 1996). The single heavy black arrow indicates the magma flow direction. Black arrows in (b): magma flow velocity. White arrows in (c): wall displacement velocity. 


\section{The magmatic component}

It can be inferred from field observations that the dykes intruded into planar fractures developed in a brittle domain. Several pieces of evidence support this inference. The sigmoidal geometry of the phenocryst shape-orientation, the stubby apophyses into the host rock, the magma infilled tension gashes with tiled phenocrysts, the parasitic asymmetric folds inside the tension gashes and host rock irregularities all point to magma intrusion into an active shear zone. Here the viscous fluids were deformed by movement along the faults, during or shortly after intrusion (see Fig. 2; Skarmeta, 1980).

The dykes of the Peninsula de Mejillones have discontinuous shear strain-width curves, in which the shear strain increases away from an internal position of zero or low strain towards the margins (Figs. 2 and 9). Steps and sudden variations in the deformation paths indicate changes in the physical conditions of the deforming material (Elliot, 1972). These discontinuities can be the result of various processes, the most relevant being the physical variations of the fluid properties (i.e., the temperatureviscosity dependence) during deformation and/or internal physical variations (i.e., compositional and size layering) that existed during deformation and progressive transition from melt to a solid aggregate (Platten and Watterson, 1987; Delaney, 1987). Based on this transition, the rheological evolution of crystallising magmas can be divided into three successive stages. For crystal volume fractions lower than about 30-40\%, the magmas are a suspension with a Newtonian behaviour where the SPO of igneous minerals is initiated. With a greater particle content the suspension acquires a rheology with yield strength. From this limit to about $60-65 \%$ of crystals (i.e., the critical melt fraction, Van der Molen and Paterson, 1979), most of the SPO develops. When the crystallinity reaches this last threshold, which corresponds to the development of a continuous framework of crystals in the presence of melt, the apparent viscosity increases significantly and the magma acquires a plastic behaviour with a very high yield strength.

Many dykes show variations in the phenocryst concentration $(\Lambda \%)$ and grain size distribution (D) across their width (Figs. 3, 10b, c and 11). These textural variations are the result of the mechanical (contact) interaction of the phenocrysts during in- trusion of magma (Figs. 10 and 11c; Komar, 1972a and b, 1976) and lead to lateral changes of viscosity (and therefore rheology), a function of phenocryst concentration (Van der Molen and Paterson, 1979). Figure $3 \mathrm{a}$ and $\mathrm{b}$ shows respectively the characteristic variations in the phenocryst concentration and grain size across basaltic dykes. These variations were measured and plotted against the $y$-axis whose widths were scaled to allow a comparison of dykes with different thicknesses (Fig. 11).

The flow differentiation hypothesis has been simulated in model experiments by Bhattacharji and Smith, (1964) and Bhattacharji, (1967) who found that solid phenocrysts tend to migrate and concentrate towards the centre of the dyke. Bagnold (1954) studied the behaviour of particles undergoing shearing between the concentric layers of differential flow velocity in cylinders and concluded that grain interaction causes them to repel one another creating conditions for establishing a grain dispersive pressure. The magnitude of this pressure is dependent upon the diameter of the grains, the shear rate, concentration of particles and the viscosity of the intergranular fluid. Rotation of large particles contained within a high concentration media $(>8 \%$ of particles, see below) may slow or even stop due to collisions (Arbaret et al., 2000).

For conditions similar to those in basaltic magmas where the grains are small in diameter and their concentration is low, the empirical relationship of Bagnold (1954) is:

$$
P_{v}=\mathrm{a}_{\mathrm{v}} \Lambda^{2 / 3} \eta \frac{\partial u}{\partial y}
$$

Where $P_{v}$ is the grain dispersive pressure, $a_{v}$ is a coefficient of proportionality close to $3, \eta$ the viscosity of the fluid portion, $\partial u / \partial y$ the shear rate and $\Lambda$ the linear concentration of the solid particles suspended in a fluid.

At a granular volume concentration of about $8 \%$, the average free distance between spherical grains is equal to the average grain diameter, thus grain interaction will be ensued (Bagnold, 1954). Since phenocryst concentrations are commonly greater than $8 \%$ their interaction during magma flow becomes very significant. For a magma with an initially uniform concentration of phenocrysts, it is apparent from equation 10 that since $\partial u / \partial y$ increases towards the walls, then $P_{v}$ will be at a maximum 

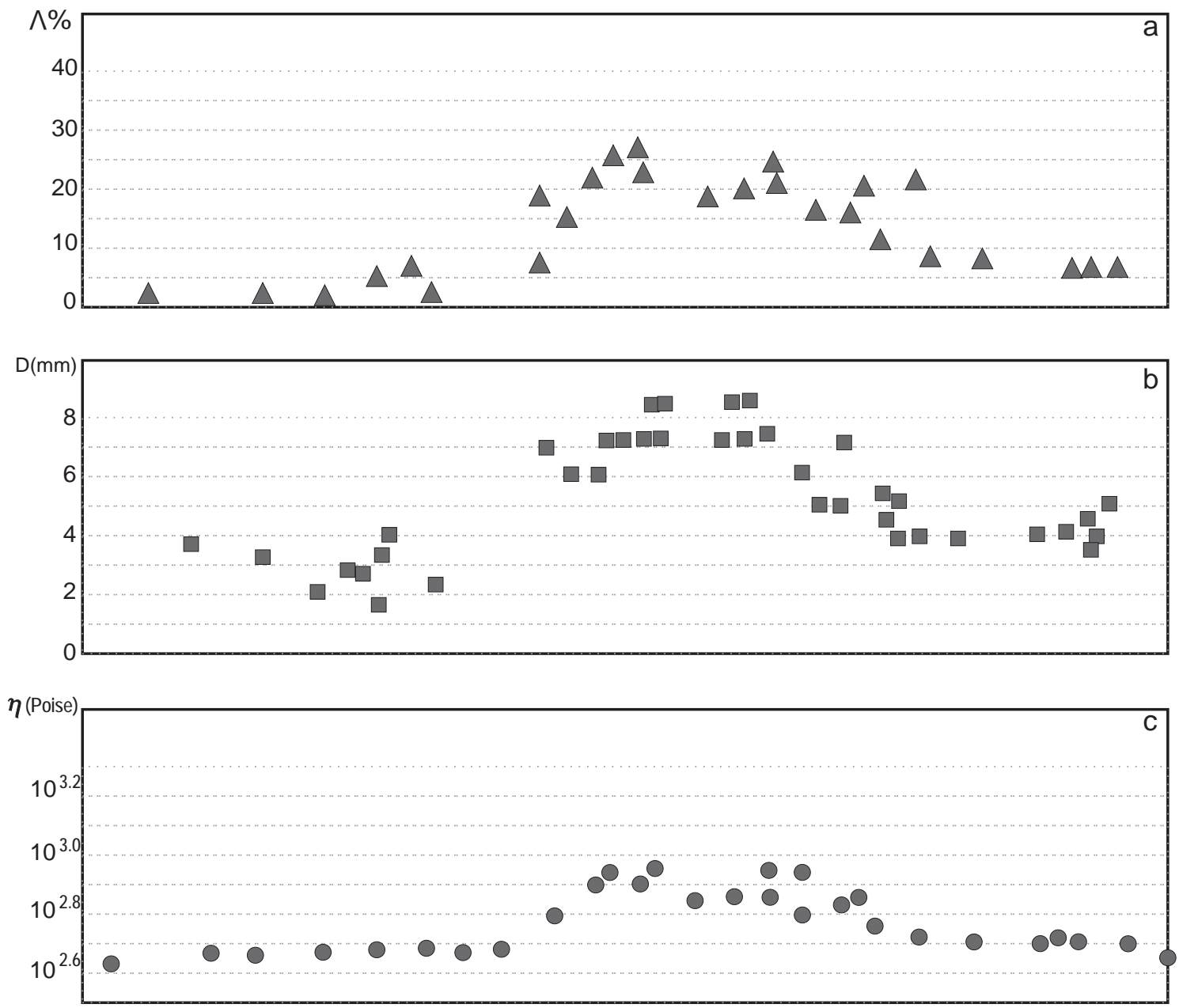

FIG. 11. a. Phenocryst concentration $(\Lambda \%)$ distribution across a dyke; b. Diameter variations $(\mathrm{D} \mathrm{mm})$; $\mathbf{c}$. Calculated viscosity variations $(\eta$ poise) as a function of the phenocryst concentration. (See discussion in text).

at the walls and will decrease to a minimum at the central part of the dyke, thereby setting up initial pressure gradients (Komar, 1972a). These gradients will cause particles to migrate away from the walls towards the centre of the dyke until equilibrium is achieved, where in the absence of other forces, the grain dispersive pressure is constant. In this case, equation 10 transforms to:

$$
P_{v}=a_{v} \Lambda^{2 / 3} \eta \frac{\partial u}{\partial y}=\text { constant }
$$

For this equilibrium to hold, the increase in $\partial u / \partial y$ towards the walls should be compensated by a decrease in the concentration $\Lambda$. The variations of the measured concentration and the diameter of crystals are as shown in figure $11 \mathrm{a}$ and $\mathrm{b}$ respectively, where the increase in both $\Lambda$ and $\mathrm{D}$ can be observed towards the centre of the dykes (see schematic representation in figure 10). The relationship between crystal concentration and the viscosity of suspensions of spheres in Newtonian liquids under isothermal conditions can be established from the Einstein-Roscoe equations (Shaw, 1969). The across-the-dykes viscosity variations are a direct function of the differential crystal concentration. As shown in figure $11 \mathrm{c}$ viscosity increases from the margins towards the centre 
following the same pattern. From equation 11 and the phenocryst concentration viscosity related variations (Figs. 10 and 11), it can be inferred that the magma velocity gradients increase towards the dyke margins and are severely reduced towards the axial central zone.

By measuring the concentration of phenocrysts across the dyke one may obtain an approximate estimation of the variations in the velocity profile related to magma flow. This is a difficult task because the value of the constant dispersive pressure (equation 11) is not known. However, the extreme value that the magma velocity can reach must be within the velocity range for steady flow. The minimum flow velocity gradient will occur where there is no cooling (no temperature gradient), close to the liquids. The maximum possible rate will be the critical velocity for setting up thermal feedback of frictional viscous heating. On the basis of magma flow rates measured in active dyke systems, a mean magma flow velocity value under hydrostatic stress has been estimated to be $1 \mathrm{~m}^{3} / \mathrm{s}$ (Delaney, 1987; Pollard, 1987; Turcotte et al., 1987). This estimate is not significantly different from the $0.7 \mathrm{~m}^{3} / \mathrm{s}$ theoretically determined by Fedotov (1978), or the 0.87 $\mathrm{m}^{3} / \mathrm{s}$ averaged by Wilson (1993) for $0.5 \mathrm{~m}$ wide basaltic dykes.

\section{Differentiated magma subject to plane shear}

The Peninsula de Mejillones post metamorphic dykes intruded into pre-existing fractures with a previous history of fracture-parallel shear that displaced syn-metamorphic aplitic dykes. This conforms to a scenario in which existing anisotropies were reactivated during magma intrusion in a process we shall call 'magmatic faulting'.

Under an external stress resulting from either the overburden or tectonism, sliding movement on pre-existing critically oriented and stressed faults may be frictionally inhibited until the static frictional resistance to shearing is overcome (Sibson, 1985). The most relevant factor with regard to fault reactivation, the associated stress drop and equilibration is the fault localized fluid overpressure that induces variations of the effective stress across the fault planes reducing frictional resistance to slip (Hubbert and Rubey, 1959; Lachenbruch, 1980). This fluid pressure increase may be the product of any liquid available at the time, including low viscosity magma. This situation will continue for so long as the fluid pressure is large enough to permit shearing along the fault. Conditions will change if the fluid pressure reduces below a limit for the necessary effective normal stress decrease, such as if the fluid (magma) escapes, or crystallization increases beyond a critical melt fraction in which the suspension will no longer hold a Newtonian behaviour.

The role of magma intrusion on fault activation or reactivation has already been addressed by Berger, 1971; Escher et al., 1976; Talbot, 1983; Lisle, 1989; Price and Cosgrove, 1990. Slip along magma-filled faults can be assimilated to viscous laminar flow in a liquid entrapped between two parallel near-planar walls of adjacent fault blocks moving in opposed motion in the $x$-direction (i.e., a coupled parallel Couette flow). It is assumed that no displacement in the $z$ direction occurs (Figs. 7 and 9). This model can be illustrated by the analytical solution of a simple geometrical configuration of a viscous material contained between two parallel plates moving at constant and opposing relative speeds, $u_{l}$ and $-u_{h}$ relative to each other (see Figs. 5 and 12).

The steady flow of uniform magma can de described in terms of one-dimensional channel flow. For Newtonian fluids with an initial constant viscosity $\eta$ it holds that (Jaeger, 1969; Middleton and Wilcock, 1994):

$$
\tau=\eta \frac{\partial u}{\partial y}
$$

The flow in the channel is determined by the equation of motion that describes the force balance on a layer of fluid. The net pressure forces in the $x$-direction should be zero, therefore the pressure gradients in the channel in terms of the equation of motion may be written:

$$
\frac{\partial \tau}{\partial y}=\frac{\partial p}{\partial x}
$$

where $\partial p / \partial x$ is the pressure gradient along the $x$ direction. By substituting the expression for $\tau$ from equation 12, the downstream pressure gradient (the $x$-component of the Navier-Stokes equation, (Bird et al., 1960) is obtained: 


$$
\eta \frac{\partial^{2} u}{\partial y^{2}}=\frac{\partial p}{\partial x}
$$

Given that equation 14 is a second order partial differential equation its integration requires two boundary conditions:

$$
\begin{aligned}
u & =\int\left(\frac{\partial p}{\eta \partial x} y+C_{1}\right) \partial y \\
& =\frac{1}{2 \eta} \frac{\partial p}{\partial x} y^{2}+C_{1} y+C_{2}
\end{aligned}
$$

In order to evaluate the constants $\mathrm{C}_{1}$ and $\mathrm{C}_{2}$, the no-slip boundary conditions $\left(u=0\right.$ at $y=0, u=-u_{h}$ at $y=h$ and $u=u_{l}$ at $y=-l$, Fig. 12) must be met (Bird et al., 1960; Schlichting, 1968). When these boundary conditions are satisfied the complete solution for equation 15 at $h \geq y \geq 0$ becomes:

$$
u=\frac{1}{2 \eta} \frac{\partial p}{\partial x}\left(y^{2}-h y\right)-\frac{u_{h} y}{h}
$$

And that for $-l \leq y \leq 0$ the solution for $u$ becomes:

$$
u=\frac{1}{2 \eta} \frac{\partial p}{\partial x}\left(y^{2}+l y\right)+\frac{u_{l} y}{l}
$$

By definition the shear strain $(\dot{y})$ can be written:

$$
\stackrel{\bullet}{\gamma}=\frac{\partial u}{\partial y}=\frac{\partial \gamma}{\partial t}
$$

and $\partial u / \partial y$ can be derived from equations 4,5 and 6 by differentiating them with respect to time. There are however, major limitations on the period during which the magma can flow. This period is taken to be the time needed for a magma, at an initial temperature of $1,200^{\circ} \mathrm{C}$ (close to the liquidus, Shaw, 1969; Fig. 13), to cool down to $1,120^{\circ} \mathrm{C}$, at which point it will no longer sustain a linear rheology and for all practical purposes will not flow. A rapid crystallization of magmas with a small temperature crystallization interval

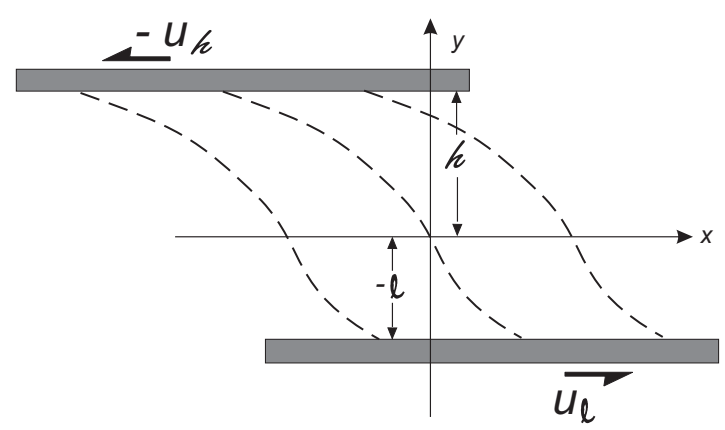

FIG. 12. Boundary conditions for shearing a viscous fluid contained between two country rock walls sliding with opposed velocity and directions. Note sign convention.

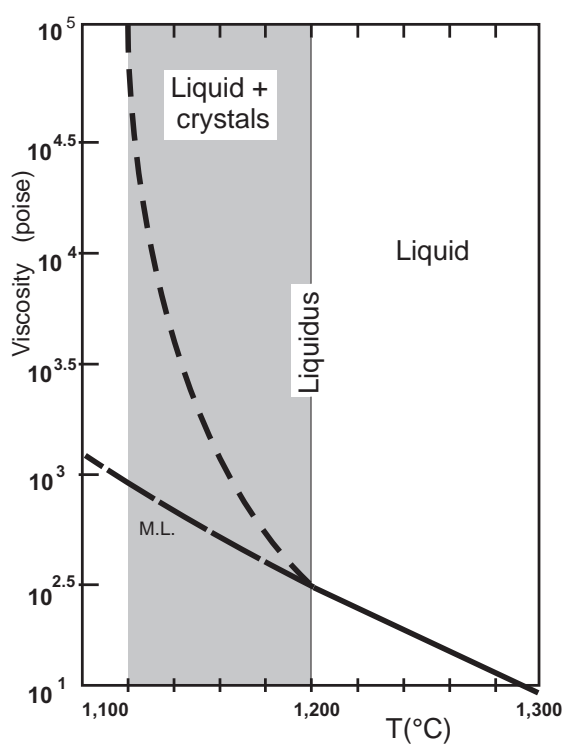

FIG. 13. Apparent viscosities of basaltic magmas at temperatures between $1,100-1,300^{\circ} \mathrm{C}$. The curve ML indicates the probable temperature dependence of liquids with no crystallization (i.e., super cooled magmas). The heavy dashed lines represent apparent viscosities as function of temperature. The shaded area indicates the temperature domain of non-linear rheology behaviour (Shaw et al., 1968 and Shaw, 1969).

will favour the preservation of an early magmatic fabric (Arbaret et al., 1996).

According to Shaw (1969), the relationship between the viscosity increase as a function of temperature decrease is given by:

$$
\eta=\eta_{0} e^{-0.23(T-T o)}
$$


where $T$ is the temperature after time $t, T_{o}=1,200^{\circ} \mathrm{C}$ is the initial temperature, and $\eta_{0}=10^{2.65}$ poise is the viscosity at the dyke margin at a temperature $T_{\mathrm{o}}$ (Fig. 13). From equation 19 we can see that at $1,120^{\circ} \mathrm{C}$ the viscosity $\eta$ is $10^{10.5}$ poise and a temperature drop of $5^{\circ} \mathrm{C}$ can increase the viscosity by several orders of magnitude (Fig. 13).

The approximate time span over which these temperature variations may occur can be estimated from the model solutions that describe the cooling history of rocks in the immediate vicinity of intrusions given by thermal equilibration of steeply inclined one dimensional temperature profiles (see Jaeger, 1968).

The time $t$, required for a dyke to cool from $1,200^{\circ} \mathrm{C}$ to $1,120^{\circ} \mathrm{C}$ is dependent on the temperature and lithology of the host rock depth of emplacement and the environment. The geological evidence that can be used for estimating the depth at which the dykes were intruded is limited to the nature of the contacts between the dykes and the host rock. In the study area on the Peninsula de Mejillones this indicates that the host rock failed in a very brittle manner at relatively shallow depths in the crust. The lower limit, or maximum depth, can be estimated by establishing the depth of the corresponding secondary supply chamber that generated the magma influx into the host fracture (Bons et al., 2001). Fedotov (1978) developed a theoretical analysis that relates the dyke thickness, the viscosity of a basaltic melt, the magma through-dyke ascent velocity and the depth of the local feeding chamber. From basaltic magma viscosities (see Shaw, 1969 and discussion below) and an appropriate range of dyke thickness, it can be estimated using the Fedotov (1978) arguments that the local source chamber would have been at a depth of $4 \pm 1 \mathrm{~km}$ below the paleo-surface.

At a depth of $4 \mathrm{~km}$, the host-rock temperature would be of the order of $\sim 320^{\circ} \mathrm{C}$, calculated from an estimated volcanic-arc thermal gradient of $\sim 80^{\circ} \mathrm{C} /$ $\mathrm{km}$ (Armstead, 1982). This number does not take into account thermal feedback processes. Based on the Jaeger (1968) error functions the cooling time $t$ can be expressed as a function of the width of the intrusive. For the conditions established above, time $t$ is approximately $27 y^{2}$ (see also Fedotov, 1978; Stüwe, 1999).

Differentiation of equation 16 yields

$$
\frac{\partial u}{\partial y}=\frac{1}{2 \eta} \frac{\partial p}{\partial x}(2 y-h)-\frac{u_{h}}{h}
$$

which combined with the differentiation of equation 5 and the dyke cooling time (estimated as a function of the dyke width, $t=27 y^{2}$, see above) leads to:

$$
\begin{aligned}
\frac{\partial \gamma}{\partial t}= & \frac{\partial \gamma_{h}}{\partial y} \times \frac{\partial y}{\partial t}=(0.2 y-0.5) \\
& \times\left(\frac{1}{54 y}\right)=\left(\frac{0.2 y-0.5}{54 y}\right)
\end{aligned}
$$

At $0 \leq y \leq h$ this equation becomes

$$
\frac{1}{2 \eta} \frac{\partial p}{\partial x}(2 y-h)-\frac{u h}{h}=\frac{0.2 y-0.5}{54 y}
$$

Making the same type of substitutions and combinations for the $l$ side of the dyke $(-l \leq y \leq 0)$ as those used for the $h$ side of the dyke (equations 7 , 17) the following is obtained:

$$
\frac{\partial u}{\partial y}=\frac{1}{2 \eta} \frac{\partial p}{\partial x}(2 y+l)+\frac{u_{l}}{l}
$$

When combined with the differentiation of equation 7 and a dyke cooling time of $t=27 y^{2}$ it follows that:

$$
\frac{1}{2 \eta} \frac{\partial p}{\partial x}(2 y+l)+\frac{u l}{l}=-\left(\frac{0.6 y+0.18}{54 y}\right)
$$

Placing $y=15 \mathrm{~cm}$ into equation 22 and $y=-10$ $\mathrm{cm}$ (see Fig. 9) into equation 24, thus making the pressure gradients $\partial p / \partial x$ in the $x$-direction equivalent, (equations 22 and 24), and for the sake of simplicity relying on numerical approximations, a value for $u_{h}$ of $2.5 u_{l}$ is obtained. From figure 5 it can be seen that $u_{h}=u+u_{m}$ and that $u_{l}=u-u_{m}$ therefore the corresponding velocities at the dyke margins become $u_{h}=3.3 u_{m}, u_{l}=1.3 u_{m}$ and therefore $u=2.3$ $u_{m}$. These figures are in good agreement with those obtained by model studies in which the strongly asymmetric shape orientations develop when $u$ is larger or much larger than $u_{m}$ (Correa-Gomes et al., 2001). Under these circumstances the finite SPO along the conduit are mainly shaped by external shearing, and strain markers with high aspect ratio deflect towards higher sigmoidal shapes due velocity additions (Fig. 6). 


\section{Stresses at the faulting-intrusion onset}

The stress field associated with the intrusion of inclined dykes is equivalent to that prevailing for hybrid extension/shear fractures. Hence, based on the Andersonian theory in a normal fault system where the principal compressive stress acts vertically, the dykes should be inclined with a minimum dip of $70^{\circ}$ (Price and Cosgrove, 1990). In rock masses with pre-existing faults or fractures, the magma may preferentially intrude into these pre-existing planes of weakness, rather than generate new vertical fractures by hydraulic fracturing if the fractures are appropriately oriented with respect to the current stress field.

Should the necessary stress conditions be met and an inclined dyke is generated by magma infilling of an existing normal fault, displacement of the country rock will ensue. The asymmetric fabrics and associated structures shown in the Peninsula de Mejillones dykes are evidence that the faults were initiated or reactivated by intrusion of magma (i.e., magmatic faulting) and that slip movement occurred while the magma was in the initial stages of cooling.

The shear stress-strain rate relationships for deforming viscous fluids are as given in equation 12 (Jaeger, 1969; Middleton and Wilcock, 1994). From the $\dot{y}-y$ distribution relationships, obtained in equations 20 and 23 , and the shear stresses resolved at the dyke margins $(y=15 \mathrm{~cm}$ and $-10 \mathrm{~cm})$ it follows that:

$$
\begin{gathered}
\tau_{y=h}=\eta \dot{\gamma}_{y}=\eta\left(\frac{0.6 y-5}{54 y}\right)=0.2 \eta \\
\tau_{y=-l}=\eta \dot{\gamma}_{l}=-\eta\left(\frac{2.26 y-13}{54 y}\right)=0.14 \eta
\end{gathered}
$$

Where $\tau_{h, l}$ is the shear stress in the $x$-direction at the sides of the dyke, i.e., $y=h$ and $y=-l$. From these equations it follows that the value of the shear stress $\tau$ at the dyke margins and at temperatures close to the liquidus $\left(\sim 1,200^{\circ} \mathrm{C}\right.$, Shaw, 1969 ; Fig. 13) is approximately $10^{-3}$ bars. Clearly, the result is a very low value. Its geological significance is that, at these temperatures, the magma did not offer resistance to shearing and faulting, and once the conduit was full, faulting activity followed.
The shear stress required at different magma temperatures is shown in figure 14 . Once the temperature has dropped to $1,120^{\circ} \mathrm{C}$ the shear stress required for fault displacement begins to increase significantly because of the onset of strongly temperature-viscosity dependence. At $1,120^{\circ} \mathrm{C}$ the viscosity increases to $10^{10.5}$ poise (Fig. 13). Equations 25 and 26 allow the shear stress required at the dyke margins to be determined for different temperatures and therefore different viscosities. For example, the shear stress at $1,120^{\circ} \mathrm{C}$ is in the range of $1-2 \times 10^{3}$ bars. This value is more than one order of magnitude higher than the commonly accepted range of values for stress release during faulting (see Fyfe et al., 1978), thus it can be concluded that dyke deformation ceased long before the rock had cooled to $1,120^{\circ} \mathrm{C}$ or before its viscosity rose to $10^{10.5}$ poise (Fig. 11).

In order to ascertain the stress parameters required for the deformation of magma that behaves as a Newtonian fluid, a comparison is made with those figures commonly quoted for stress releases after earthquake faulting. The accepted static shear stress drop averaged over the surface of medium to large earthquake ruptures lies between 10-100 bar (Kanamori and Anderson, 1975). The average value for plate boundary earthquakes is $\sim 30$ bars, although Hanks (1977) found that, irrespective of the earthquake size, stress drops lie in the range of 1-100 bar. Higher stress drops may nevertheless occur locally around asperities. Thus it seems reasonable to establish a 30-100 bar shear stress release range.

Based on these commonly accepted fault stress drop values, a recalculation of the maximum viscous shear-displacement times based on the Jaeger (1968) temperature decay error-functions yield an equivalent temperature of $1,143^{\circ} \mathrm{C}$, that corresponds to a viscosity of $10^{8.3}$ poise. The required shear stresses at the dyke margins and centre with this re-calculated viscosities are 20-30 bars and only a fraction of a bar at $y=0$, respectively. Thus there is a severe stress gradient from the margin towards the centre of the dyke, where the shear strain is close to zero, crystal concentration and interaction is maxima and mobility is low (Fig. 14).

From equation 18 it is apparent that just a few degrees below a critical temperature the viscosity will increase its value by several orders of magnitude, prompting an increase in the magnitude of the shear stresses required for viscous magmatic 


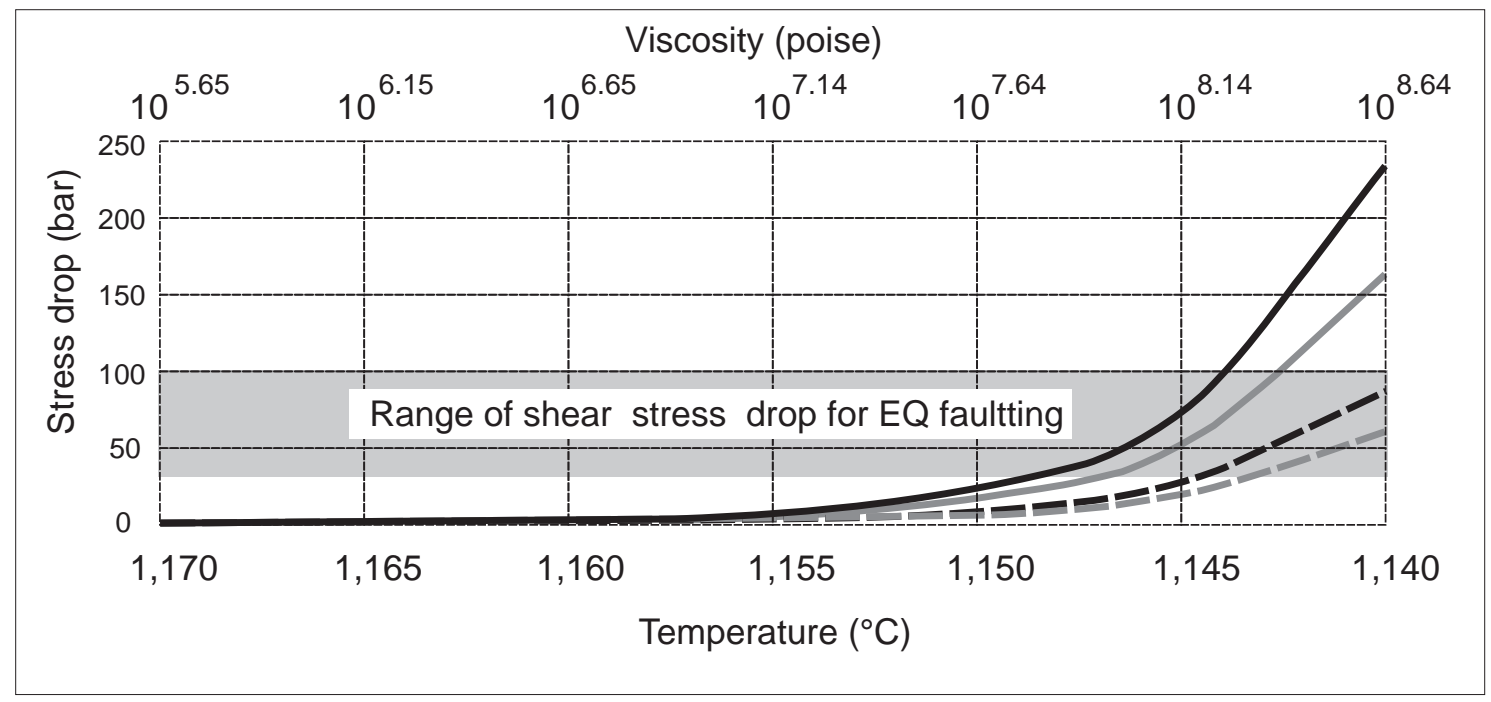

FIG. 14. Calculated shear and differential stress drops as a function of viscosity and temperature variations for the Peninsula de Mejillones dykes. Heavy lines correspond to drops in differential stress, segmented lines to shear stress. Black curves represent negative values ( $l$ wall of the dyke) and grey ones positive values ( $h$ wall of the dyke, see figures 9 and 12 for sign convention). Note that at $<1,140^{\circ} \mathrm{C}$ the differential stress drops become several orders of magnitude higher than those commonly accepted for faulting, indicating that 'magmatic-faulting' ceased before the magma cooled to the temperature in which its linear Newtonian $\left(1,120^{\circ} \mathrm{C}\right.$ ) behaviour was lost, (see text for discussion and figure 13 ).

faulting. When the crystal content in the presence of melt reaches $60-65 \%$ the viscosity will increase significantly and the magma will acquire a plastic behaviour with very high yield strength. For example at $1,080^{\circ} \mathrm{C}$ the viscosity rises to $10^{14.5}$ poise and the corresponding shear stress will be on the order of $3 \times 10^{3} \mathrm{Kbar}$, several orders of magnitude above the accepted shear stress drop numbers. In contrast the estimated values of the stress drop at or below $1,143^{\circ} \mathrm{C}$ are in the range of 20-30 bars (Fig. 14).

The shear stresses requirements for re-shearing of cohesion-less fault is given by (Jaeger, 1969):

$$
\tau_{\max }=\eta \dot{\gamma}
$$

Using this equation to determine the shear stress $\tau_{\max }$ at $y=-10$ and $y=15$ it can be seen that below $1145^{\circ} \mathrm{C}$ the required shear stresses will be on the range of $40 \pm 10$ bars, (see Figs. 14 and 12 for sign convention). In the case of a normal fault, dipping at $70^{\circ}$, i.e., at an angle of $20^{\circ}$ with respect to the maximum (vertical) principal stress axis $\left(\sigma_{v}=\sigma_{1}\right)$, the differential stresses can be determined from the shear stress values for a range of temperatures (and therefore viscosities, Fig. 14), using the standard shear stress equation:

$$
\tau=\frac{\left(\sigma_{1}-\sigma_{3}\right)}{2} \sin 2 \alpha
$$

Placing a $\tau$ value of 40 bars into equation 28 (Fig. 14), a differential stress $\left(\sigma_{1}-\sigma_{3}\right)$ of $\sim 100$ bar is obtained at the time of fault reactivation and/or magma intrusion. If it is assumed that deformation took place at a depth of $4 \mathrm{~km}$, and that the structural controls that govern the orientation of the principal stress axes established by Anderson (1951) hold, then $\sigma_{1}=\sigma_{v}=\rho \times g \times 4 \mathrm{~km}$ or 1,120 bar for a density $\rho$ of $2.8 \mathrm{gr} / \mathrm{cm}^{3}$ and a $g$ value of $10^{3} \mathrm{~cm} / \mathrm{sec}^{2}$. This means that at $4 \mathrm{~km}$ depth the horizontal stress $\left(\sigma_{3}\right)$ was close to 1,017 bar, implying that at that depth the state of stress was close to hydrostatic pressure as $\sigma_{1} \sim \sigma_{3}$. This conclusion is consistent with that attained by Townend and Zoback (2000) who established that in a fault controlled upper crust the permeability is hydrostatically maintained by fluid pressure. This fluid equilibration will be sustained by critically stressed faults that facilitate equilibrium throughout the crust by continual small 
scale faulting that enhances fluid redistribution. Similar conclusions have been drawn by Shaw (1980), who states that active-collapsing volcanic centres sustain higher differential stresses than expected given that volcanic bulk permeability is accommodated by a mesh of interconnected dykes and faults in the Hill (1977) sense such that under hydrostatic stress the interconnective complex will locally and transiently transfer and redistribute the local excess magma pressures.

\section{Conclusions}

The dyke swarm system exposed within the Peninsula de Mejillones intrudes mylonite and cataclasite of a foliated basement. The dykes correspond to the feeder structures of a deeply eroded Jurassic volcanic arc. Contact relationships suggest intrusion along pre-existing fractures. The internal deformation structures of the dykes include asymmetric shape preferred orientation paths formed by the alignment of oriented pyroxene laths. These crystals indicate a rotational sense of movement compatible with that of conjugate normal faults with $z$ and $s$ SPO asymmetries shown in figure 1.

The nature of the contacts, coupled with the internal fabric allows a distinction to be made between the flow structures and a superimposed tectonic deformation. The preferred orientation fabric is developed from an inhomogeneous lath suspension in a consolidating fluid that variously reflects the shear strains developed during the flow of segregated magma (Fig. 10). An analysis of the SPO shows that shear strain and displacement paths are discontinuous across dykes, with breaks largely related to variations in the size and concentration of phenocrysts. The compromise between internal and external stress components in the imprint of finite strain on the dykes leads to the conclusion that the external tectonic-related stress displacement velocities $( \pm u)$ are more than three times larger than the internal, magma flow related velocities $\left(u_{m}\right)$, indicating that the prominent asymmetrical fabrics are largely modelled by external shear rather than by magmatic flow (Fig. 6e).

Quantification of the deformation history was achieved by balancing the apparent net pressure gradients and forces applied on to the dykes, the cooling times of magma within linear Newtonian boundaries, the viscous shear stresses required for such deformation and the relevant equations for the viscous processes. It is concluded that on a geological timescale, flow and deformation were instantaneous, and stopped abruptly because of the brief time required for the magma temperature to fall to the immobility limit. At the $1,140^{\circ} \mathrm{C}$ threshold, a small drop in temperature induces a viscosity increase of more than two orders of magnitude such that the magmatic faulting becomes inhibited because of the large shear stresses required for further movement on the magma filled faults (Fig. 14).

The estimated shear stress, compatible for simultaneous fault displacement and viscous shearing of the magma is in the order of $40 \pm 10$ bars for average dyke widths. For a normal conjugate fault system the corresponding differential stress is in the order of 100 bars, which at a depth of $4 \mathrm{~km}$ becomes a quasi-hydrostatic state of stress. In a critically stressed, fault controlled upper crust, it is argued that the magma pressure will induce continuous faulting which will help to maintain an overall stress state close to hydrostatic equilibrium (Townend and Zoback, 2000).

Similar states of stress have been determined to occur in collapsing volcanic centres or arcs (Shaw, 1980) where differential stress is accommodated by meshes of interconnected dykes and faults (Hill, 1977) that locally and transiently transfer and redistribute the excess magma pressure.

\section{Acknowledgements}

I would like to thank Mr. C. Huete (Exploration ManagerCodelco Chile) for authorizing the publication of the paper. I am grateful to the late Dr. P. Carrasco (Codelco Chile), Dr. G. Yáñez (Universidad Católica de Chile), and Dr. E. Godoy (Dirección General de Aguas, Chile) for helpful reviews of an original version of the manuscript. Dr. E. Moores (University of California, USA) and especially Dr. C. Mortimer (James Cook University, Australia) are acknowledged for thorough reviews of the manuscript, and Professors J. Cosgrove (Imperial College, London) and J. Karson (University of Syracuse, USA) for thoughtful comments that helped to improve the paper.

\section{References}

Anderson, E.M.1951. The Dynamics of Faulting. Oliver and Boyd: 191 p. Edinburgh.

Armstead, H.C. 1982. Geothermal Energy. E and F.N. Spon Ltd.: 404 p. London. 
Arbaret, L.; Fernández, A.; Jezek, J.; Ildefonse, B.; Launeau, P.; Diot, H. 2000. Analogue and numerical modeling of shape fabrics: application to strain and flow determinations in magmas. Transactions of the Royal Society of Edinburgh: Earth Sciences 90: 97-109.

Arbaret, L.; Diot, H.; Bouchez, J.L. 1996. Shape fabrics in low suspensions: 2D analogue experiments and application to tiling in magma. Journal of Structural Geology 18: 941-950.

Baer, G. 1995. Fracture propagation and magma flow in segmented dykes: field evidence and fabric analyses, Maktesh Ramon, Israel. In Physics and Chemistry of Dykes (Baer, G.; Heimann, A.; editors). Balkema: 125-140. Rotterdam.

Baeza, L. 1984. Petrography and tectonics of the plutonic and metamorphic complexes of Limon Verde and Mejillones Peninsula, Northern Chile. Doctoral Thesis University of Tubingen: $205 \mathrm{p}$.

Bagnold, R.A. 1954. Experiments on gravity-free dispersion of large solid spheres in a Newtonian fluid under shear. Royal Society London Proceedings Serie A 225: 49-63.

Benn, K.; Allard, B. 1989. Preferred mineral orientation related to magmatic flow in ophiolitic layered gabbros. Journal of Petrology 30: 925-946.

Berger, A.R. 1971. Dynamic analysis using dikes with oblique internal foliations. Geological Society of America Bulletin 82: 781-786.

Bhattacharyya, D.S. 1966.Orientation of mineral lineation along the flow direction in rocks. Tectonophysics 3: $1-25$.

Bhattacharji, S. 1967. Mechanics of flow differentiation in ultramafic and mafic sills. Journal Geology 75: 101-112.

Bhattacharji, S.; Smith, C.H. 1964. Flowage differentiation. Science 145 (3628): 150-153. DOI: 10.1126/ science.145.3628.150

Bird, R.B.; Stewart, W.E.; Lightfoot, E.N. 1960. Transport Phenomena. John Willey and Sons: 780 p. New York.

Blumenfeld, P.; Bouchez, J-L. 1988. Shear criteria in granite and migmatite deformed in the magmatic and solid states. Journal of Structural Geology 10 (4): 361-372. DOI: 10.1016/0191-8141(88)90014-4

Bons, P.D.; Dougherty-Page, J.; Elburg, A. 2001. Stepwise accumulation and ascent of magmas. Journal of Metamorphic Geology 19: 625-631.

Clemente, C.S.; Beamud, E.; Garcés, M. 2007. Dike intrusion under shear: Effects on magnetic and vesicle fabrics in dikes from rift zones of Tenerife (Canary Islands). Journal of Structural Geology 29: 1931-1942.

Correa-Gomes, L.C.; Souza-Filho, C.R.; Martins, C.J.; Oliveira, E.P. 2001. Development of symmetrical and asymmetrical fabrics in sheet-like igneous bodies: the role of magma flow and wall-rock displacements in theoretical and natural cases. Journal of Structural Geology 23: 1415-1428.

Cortés, J.; Marquardt, C.; González, G, Wilke, H-G.; Marinovic, N. 2007. Cartas Mejillones y Península de Mejillones, Región de Antofagasta. Servicio Nacional de Geología y Minería, Carta Geológica de Chile, Serie Geología Básica 103-104: 58 p.

Coward, M. 1983. The analysis of flow profiles in a basaltic dyke using strained vesicles. Journal Geological Society of London 137: 605-615.

Delaney, P.T. 1987. Heat transfer during emplacement and cooling of mafic dykes. In Mafic Dyke Swarms (Halls, H.C.; Fahig, W.F.; editors). Geological Association of Canada, Special Paper 34: 25-46.

Delaney, P.; Pollard, D. 1981.Deformation of host rocks and flow of magma during growth of minette dikes and breccia-bearing intrusions near Ship Rock, New Mexico. U.S Geological Survey Professional Paper 1202: $61 \mathrm{p}$.

Den Tex, E. 1969. Origin of ultramafic rocks. Their tectonic setting and history. Tectonophysics 7 : 457-488.

Elliot, D. 1972. Deformation paths in structural geology. Geological Society of America Bulletin 83: 2621-2638.

Escher, A.; Jack, S.; Watterson, J. 1976. Tectonics of the North Atlantic Proterozoic dyke swarm. Philosophical Transactions of the Royal Society of London A 280: 529-539.

Fedotov, S.A. 1978. Ascent of basic magmas in the crust and the mechanism of basaltic fissure eruptions. International Geology Reviews 20 (1): 33-48.

Ferraris, F.; Di Biase, F. 1978. Hoja Antofagasta, Región de Antofagasta. Instituto de Investigaciones Geológicas de Chile, Carta Geológica de Chile 30: 48 p., 1 mapa escala 1:250.000.

Fyfe, W.S.; Price, N.J.; Thompson, A.B. 1978. Fluids in the Earth's Crust. Elsevier: 383 p. Amsterdam.

Gay, N.C. 1968. Pure shear and simple shear deformation of inhomogeneous viscous fluid. I Theory. Tectonophysics 5 (4): 211-234.

González, G. 1996. Evolución Tectónica de la Cordillera de la Costa de Antofagasta Chile: Con especial referencia a las deformaciones sinmagmáticas del Jurásico- 
Cretacico Inferior. Doctoral Thesis (Unpublished), University of Berlin: $105 \mathrm{p}$.

Hanks, T. 1977. Earthquake stress-drops, ambient tectonic stresses, and stresses that drive plates. Pure and Applied Geophysics 115: 441-458.

Hartley, A.J.; Turner, P.; Rex, D.C.; Flint, S. 1992. Palaeomagnetic, geo-chronological and geological constraints on the tectonic evolution of the Mejillones Peninsula, northern Chile. Geological Journal 27: 59-74.

Hill, D.P. 1977. A model for earthquake swarms. Journal of Geophysical Research 82 (8): 1347-1352. DOI: 10.1029/JB082i008p01347

Hippert, J.F.M. 1993. 'V' pull-apart microstructures: a new shear sense indicator. Journal of Structural Geology 15: 1393-1404.

Hubbert, M.K.; Rubey, W.W. 1959. Role of fluid pressure in the mechanics of overthrust faulting. Geological Society of America Bulletin 70: 115-205.

Ildefonse, B.; Launeau, P.; Bouchez, J.-L.; Fernández, A. 1992. Effect of mechanical interactions on the development of shape preferred orientations: a two dimensional experimental approach. Journal of Structural Geology 14: 73-83.

Jaeger, J.C. 1968. Cooling and solidification of igneous rocks. In Basalts: The Poldervaart Treatise on Rocks of Basalt Composition (Hess, H.H.; Poldervaart, A.; editors). Wiley Interscience New York 2: 503-36.

Jaeger, J.C. 1969. Elasticity, fracture and flow. Metheun: 267 p. London.

Jeffrey, G.B. 1922. The motion of ellipsoidal particles immersed in a viscous fluid. Proceedings of the Royal Society of London 102: 201-211.

Kanamori, H.; Anderson, D.L. 1975.Theoretical basis of some empirical relations in seismology. Bulletin Seismology Society America 65: 1073-1095.

Komar, P.D. 1972a. Mechanical interactions of phenocrysts and the flow differentiation of igneous dikes and sills. Geological Society of America Bulletin 83: 973-988.

Komar, P.D. 1972b. Flow differentiation in igneous dikes and sills: profiles of velocity and phenocryst concentration. Geological Society of America Bulletin 83: 3443-3448.

Komar, P.D. 1976. Phenocryst interactions and velocity profiles of magma flowing through dykes and sills. Geological Society of America Bulletin 87: 1336-1342.

Lachenbruch, A.H. 1980. Frictional heating, fluid pressure, and the resistance to fault motion. Journal of Geophysical Research 85 (B11): 6097-6112.
Lisle, R.J. 1989. Paleostress analysis from sheared dike sets. Geological Society of America Bulletin 102: 968-972.

Merle, O. 1998. Internal strains within lava flows from analogue modelling. Journal of Volcanology and Geothermal Research 81 (3-4): 198-206.

Middleton, G.V.; Wilcock, P.R. 1994. Mechanics in the Earth and Environmental Sciences. Cambridge University Press, Cambridge: 459 p.

Paterson, S.R.; Vernon, R.H.; Tobisch, O.T. 1989. A review of criteria for the identification of magmatic and tectonic foliations in granitoids: Journal of Structural Geology 11: 349-363.

Platten, L.M.; Watterson, J. 1987. Magma flow and crystallization in dyke fissures. In Mafic Dyke Swarms (Halls, H.C.; Fahig, W.F.; editors). Geological Association of Canada, Special Paper 34: 65-73.

Price, N.J.; Cosgrove, J.W. 1990. The Interpretation of Geological Structures, Cambridge University Press, London: $506 \mathrm{p}$.

Pollard, D.D. 1987. Elementary fracture mechanics applied to the structural interpretation of dykes. In Mafic Dyke Swarms (Halls, H.C.; Fahig, W.F.; editors). Geological Association of Canada, Special Paper 34: 5-24.

Ramsay, J.G.; Graham, R. 1970. Strain variation in shear belts. Canadian Journal of Earth Sciences 7: 786-813.

Ramsay, J.G.; Huber, M.I. 1983. The Techniques of Modern Structural Geology. Strain Analysis. New York, Academic Press 1: 302 p.

Ranilli, G. 1987. Rheology of the Earth.Deformation and Flow Processes in Geophysics and Geodynamics. Allen and Unwin: 366 p. Boston.

Rickwood, P.C. 1990. The anatomy of a dyke and the determination of propagation and magma flow. In Mafic dyke and emplacement mechanisms (Parker, A.J.; Rickwood, P.C.; Tucker, D.H.; editors): 81-100.

Rubin, A.M. 1995. Propagation of magma filled cracks. Annual Review of Earth and Planetary Sciences 23: 287-336.

Schlichting, H. 1968. Boundary Layer Theory. Mc. Graw Hill Co.: p. 647. New York.

Sibson, R.H. 1985. A note on fault reactivation. Journal of Structural Geology 7: 751-754.

Shaw, H. 1969. Rheology of basalts in the melting range. Journal of Petrology 10: 510-535.

Shaw, H.R. 1980. The fracture mechanism of magma transport from the mantle to the surface. In Physics of Magmatic Processes (Hargraves, R.B.; editor). Princeton University Press: 201-264. Princeton. 
Shaw, H.; Wright, T.L.; Peck, D.L.; Okamura, R. 1968. The viscosity of basaltic magma: an analysis of field measurments in Makaopoui lava lake, Hawaii. Journal of Petrology 266: 252-271.

Skarmeta, J. 1980. Análisis estructural de diques deformados en la Península de Mejillones, Norte de Chile. Revista Geológica de Chile 9: 3-16.

Skarmeta, J.; Suárez, M. 1979. Complejo granítico-gabroico milonitizado de la Península de Mejillones: Nota preliminar. In Congreso Geológico Chileno, No. 2, Actas I: B147-B162. Arica.

Smith, R.P. 1987. Dyke emplacement at the Spanish Peaks, Colorado. In Mafic Dyke Swarms (Halls, H.C.; Fahig, W.F.; editors). Geological Association of Canada, Special Paper 34: 47-54.

Stüwe, K. 1999. Geodynamics of the Lithosphere. SpringerVerlag, Berlin: 449 p.

Talbot, C.J. 1983. Obliquely foliated dikes as deformed incompetent single layers. Geological Society of America Bulletin 93 (5): 450-460.

Tikoff, B.; Teyssier, C. 1994. Strain and fabric analyses based on porphyroclasts interaction. Journal of Structural Geology 16: 477- 491.

Townend, J.; Zoback, M.D. 2000. How faulting keeps the crust strong. Geology 28: 399-402.

Turcotte, D.L.; Emerman, S.H.; Spence, D.A. 1987. Magma flow and crystallization in dyke fissures. In Mafic Dyke Swarms (Halls, H.C.; Fahig, W.F.; editors). Geological Association of Canada, Special Paper 34: 65-74.

Van der Molen, I.; Paterson, M.S. 1979. Experimental deformation of partially melted granite. Contributions to Mineralogy and Petrology 70: 299-318.

Wilson, L. 1993. Mecanismos eruptivos. In La Volcanología Actual (Marti-Vicente Araña, J.; editor). Consejo de Investigaciones Científicas, Madrid. Colección Nuevas Tendencias 21: 45-97.

Manuscript received: June 09, 2009; revised/accepted: April 27, 2011; available online: June 03, 2011. 